\title{
ASSESSMENT OF CHANGES IN THE OCCURRENCE OF FUSARIUM TOXIN AND OCHRATOXIN A IN POLAND RELATED TO EXTREME WEATHER PHENOMENA
}

\author{
Jacek Postupolski ${ }^{1}$, Andrzej Starski ${ }^{1}$,Ewa Ledzion ${ }^{l}$, Jolanta Kurpińska-Jaworska ${ }^{l}$, \\ Małgorzata Szczęsna ${ }^{1}$
}

${ }^{1}$ National Institute of Public Health-National Institute of Hygiene, Department of Food Safety, Warsaw, Poland

\begin{abstract}
Background. Mycotoxins - substances harmful to humans, are ubiquitous in the environment. Mycotoxins are generated primarily by Penicilium, Aspergillus and Fusarium genus fungi. Their presence is associated with the unavoidable presence of mold fungi in the environment. The presently observed adverse climatic changes could negatively affect agriculture, causing erosion and loss of organic matter from soil, promulgation of pests and plant diseases, including those originating from pathogenic molds, and also migration of certain mold species into new regions, ultimately creating more favorable conditions for generation of mycotoxins.

Objective. The purpose of this work was to investigate contamination of cereals in Poland with Fusarium and ochratoxin A. Elucidating a correlation between precipitation levels in the individual Provinces and reported levels of the investigated mycotoxins, referring to the generally available meteorological databases, would result in more efficient planning of sampling processes and focusing further preventive actions associated with establishing sampling plans for the following years.

Material and methods. Investigations were performed on cereal and cereal product samples taken by the official foodstuffs inspection staff. Some 100 samples were taken annually in the 2009-2012 period (357 samples in total). Tests were performed using high performance liquid chromatography coupled with mass spectrometry (HPLC-MS/MS). Precipitation data were obtained from the Central Office of Statistics, based on data received from the Institute of Meteorology and Water Management.

Results. Analysis of the influence of precipitation levels during vegetation period on mycotoxin levels in the investigated foodstuffs was performed by associating each recorded content of deoxynivalenol ( $\mathrm{n}=52$, corresponding to $14.6 \%$ tested samples), zearalenone $(n=30,8.4 \%)$, total T-2 and HT-2 toxins $(n=21,5.9 \%)$ and ochratoxin A $(n=88,24.6 \%)$ above quantification limit with precipitation levels within the Province from which the sample originated. Deoxynivalenol and zearalenone levels show distinct variability corresponding with variability of precipitation levels, well reflecting the reported higher deoxynivalenol and zearalenone levels observed during the rainy years of 2011-2012. Variability in average ochratoxin A levels was not statistically significant. The relatively higher mycotoxin levels in 2009 may result from the heavy rainfall and flooding of 2007-2008. Dependence between the precipitation levels and number of samples showing levels above quantification limit has been also observed for deoxynivalenol. However, a similar analysis made for zearalenone and ochratoxin A does not point to any significant relationship. No data analysis was possible in reference to total T-2 and HT-2 toxins content due to the insufficient number of results available. However, it should be noted that $21 \%$ analyzed samples in 2009 contained T-2 and HT-2 levels above the quantification limit, with average of $8.9 \mu \mathrm{g} / \mathrm{kg}$, whereas in 2010-2012 only one sample of the 263 tested contained contaminants in quantities above the quantification limit.

Conclusions. The model used for forecasting presence of mycotoxins in cereals does not allow its practical application during routine generation of official control and monitoring plans on national scale. Notably, tests performed show that exceeding of maximum contamination levels occurred just incidentally, notwithstanding the adverse weather conditions. Further systematic collection of data on mycotoxin contamination of agricultural crops is required for effective continued investigations.
\end{abstract}

Key words: mycotoxins, cereal products, formation, weather condition, prediction, Fusarium toxin, ochratoxin A

Corresponding author: Jacek Postupolski, National Institute of Public Health-National Institute of Hygiene, Department of Food Safety, 24 Chocimska Street, 00-791 Warsaw, Poland, tel. +48 225421 314, e-mail: jpostupolski@pzh.gov.pl

(C) Copyright by the National Institute of Public Health - National Institute of Hygiene 


\section{STRESZCZENIE}

Wprowadzenie. Mikotoksyny - związki o niepożądanym działaniu dla człowieka są powszechne w środowisku. Są wytwarzane głównie przez grzyby z rodzajów Penicilium, Aspergillus i Fusarium. Ich występowanie jest związane z nieuniknioną obecnością grzybów pleśniowych w środowisku. Niekorzystne zmiany klimatyczne, jakie obecnie są obserwowane, mogą spowodować niekorzystne zmiany w rolnictwie, takie jak erozja i utrata materii organicznej z gleby, rozpowszechnianie się szkodników i chorób roślin, w tym wywołanych przez patogenne pleśnie, jak również migrację niektórych gatunków pleśni na nowe regiony, oraz stworzyć dogodniejsze warunki do wytwarzania mikotoksyn.

Cel. Celem pracy było zbadanie zanieczyszczenia toksynami Fusarium i ochratoksyną A zboża w Polsce i stwierdzenie korelacji pomiędzy wielkością opadów na terenie poszczególnych województw a poziomami badanych mikotoksyn, z wykorzystaniem powszechnie dostępnych baz danych meteorologicznych, co pozwoliłoby na wydajniejsze planowanie pobierania próbek oraz skoncentrowanie dalszych działań zapobiegawczych przy tworzeniu planów pobierania próbek na następne lata. Materiały i metody. Materiał do badań stanowiły próbki zboża i produktów zbożowych pobrane przez pracowników urzędowej kontroli żywności. Pobrano po ok. 100 próbek w okresie 2009-2012 (łącznie 357 próbek). Do badań zastosowano metodę wysokosprawnej chromatografii cieczowej sprzężonej z spektrometrią mas (HPLC-MS/MS). Dane dotyczące opadów pochodziły ze strony Głównego Urzędu Statystycznego, gdzie wykorzystano dane Instytutu Meteorologii i Gospodarki Wodnej Wyniki. W celu analizy wpływu poziomu opadów w okresie wegetacji na poziomy mikotoksyn w badanych środkach spożywczych każdej zarejestrowanej zawartości powyżej granicy oznaczalności deoksyniwalenolu $(\mathrm{n}=52$, co odpowiada $14,6 \%$ zbadanych próbek), zearalenonu ( $\mathrm{n}=30,8,4 \%)$, sumy toksyn T-2 i HT-2 $(\mathrm{n}=21,5,9 \%)$ oraz ochratoksyny A $\mathrm{n}=88$, $24,6 \%)$ przypisano wartość opadów na terenie danego województwa, z którego pochodziła próbka. W przypadku deoksyniwalenolu i zearalenonu wyraźnie widoczna jest zmienność poziomów tych mikotoksyn, która jest adekwatna do zmiany poziomu opadów, dobrze odzwierciedlając wyższe poziomy deoksyniwalenolu i zearalenonu w deszczowych latach 20092010, względem bardziej suchych lat 2011-2012. Zmienność średniego poziomu ochratoksyny A nie jest istotna statystycznie. Relatywnie wyższy poziom mikotoksyn w latach 2009 może wynikać z bardzo deszczowych i powodziowych lat 2007-2008. Dla deoksyniwalenolu współzależność obserwuje się także pomiędzy poziomem opadów, a liczbą próbek powyżej wartości granicy oznaczalności. Jednak podobna analiza dla zearalenonu i ochratoksyny A, nie wskazuje na istotną zależność. Z uwagi na niewystarczającą liczbę wyników, nie była możliwa analiza danych w odniesieniu do sumy toksyn T-2 i HT-2. Należy jednak odnotować, że w 2009 roku 21\% zbadanych próbek zawierało poziom toksyn T-2 i HT-2 powyżej granicy oznaczalności, a wartość średnia wyniosła $8,9 \mu \mathrm{g} / \mathrm{kg}$, w kolejnych latach tj. 2010-2012 zarejestrowano zaledwie jedną próbkę spośród 263 zbadanych zawierającą poziom zanieczyszczenia powyżej granicy oznaczalności.

Wnioski. Zastosowany model przewidywania występowania mikotoksyn w zbożach nie pozwala na praktyczne zastosowanie go w podczas rutynowego tworzenia planów urzędowej kontroli i monitoriungu w skali całego kraju. Należy stwierdzić, że mimo niekorzystnych warunków pogodowych, jakie wystąpiły w trakcie realizacji badań, przekroczenia najwyższych dopuszczalnych poziomów zanieczyszczenia pojawiały się incydentalnie

Słowa kluczowe: mikotoksyny, produkty zbożowe, zjawiska pogodowe, przewidywanie, toksyny Fusarium, ochratoksyna A

\section{INTRODUCTION}

Consequences of climatic changes have aroused attention of researchers and the public opinion. European Commission report for central Europe (Poland, Czech Republic, Slovakia, Hungary, northern Romania, eastern Austria, southern and eastern Germany) forecasts the possibility of average annual temperature increases by $3-4{ }^{\circ} \mathrm{C}$, increased precipitation in winter and reduced in summer, along with increased risk of flooding. This could lead to adverse changes in agriculture, including erosion and loss of organic material from soil, spreading of pests and plant diseases, including those caused by pathogenic molds, into new regions, favoring generation of mycotoxins - toxic secondary metabolites - from species considered until now to be non-toxin generating $[14,15,16]$.

Mycotoxins - substances harmful to humans, are ubiquitous in the environment, with Penicilium, Aspergillus and Fusarium genus being the principal sources thereof. Their presence is associated with the unavoidable presence of mold fungi in the environment. Mycotoxins are present in agricultural products having fundamental importance for humans in cereals (aflatoxins, ochratoxin A, Fusarium toxins) in oil seeds (aflatoxins) and their processed products. Their presence has been reported in other foodstuffs, such as nuts, spices, dried fruit, coffee, wine, processed fruit products (aflatoxins, ochratoxin A, patulin). Their presence has been reported also in animal derived raw materials, transferred in mycotoxin contaminated feed. Mycotoxins are stable when subjected to majority of processes used in the food processing industry, including resistance to elevated temperatures. These substances are important acute toxins, are carcinogenic, immunotoxic nephro- and hepa-toxic $[2,3,9]$.

Considerable progress in food toxicology and development of analytical techniques over the last few years focused attention to toxins generated by the Fusarium genus fungi, widespread in the moderate climate zone, including rural areas of Europe. The genus has been found mainly in cereals and cereal products. Fusarium toxins are generated in result of (cereal) plant infection in field, during florescence. 
Hence, their abundance depends on climatic conditions prevalent using the vegetation period, with increased precipitation and high moisture content during cereal florescence resulting to with the, so-called, "Fusarium years" $[6,13,19]$, when toxin levels become exceedingly high. The toxins constitute a group of substances with differentiated chemical structure and wide spectrum of toxic action. Toxicological assessment has been performed so far for the following Fusarium toxins: deoxynivalenol (DON), nivalenol (NIV), T-2 and HT-2 toxins, zearalenone (ZEA) and fumonisin (FB) $[9,10,11,21,23]$.

Ochratoxin A (OTA) is generated in moderate climate principally by Penicillium verrucosum and is included into the group of the, so called, storage toxins exuded, among others, during storage of grain under inappropriate conditions (too high moisture content). Ochratoxin A has widespread and well documented harmful action, i.e. is nephro-toxic, teratogenic, immunotoxic and probably also neuro-toxic.

Floods ravaged many east European countries in May and June 2010. Heavy rainfall on 14-18 May led to water level increases in the upper Vistula and Odra Rivers basins. The second flood wave was caused by intensive precipitation on 1-2 June. Many embankments were broken, particularly in the Śląskie, Małopolskie, Podkarpackie, Świętokrzyskie, Lubelskie and Dolnośląskie provinces. Press reported flooding of approx 554,000 hectares and 30,000 people had to be evacuated.

Therefore, it was decided to determine the changes in mycotoxin levels present in samples of cereal products originating from different areas of Poland from harvests of 2010 (when those catastrophic widearea floods occurred) and over the following years., and to assess the changes in exposure of people to the above stated toxins.

The prevailing food laws impose preparation of annual official control and monitoring sampling plans required by the food control office. Such plans serve both to verify compliance with the applicable regulations as well as for early detection of risk factors, thus enabling activities eliminating the hazards and mitigating risks to human health $[4,8]$.

The purpose of this work was to investigate whether contamination of cereals in Poland with mycotoxins (Fusarium and ochratoxin A) is related in any way with data from generally available meteorological databases. Elucidating a correlation between precipitation levels in the individual Provinces and reported levels of Fusarium and ochratoxin A would result in more efficient planning of sampling processes and focusing further preventive actions associated with establishing sampling plans for the following years.

\section{MATERIAL AND METHODS}

\section{Samples}

Cereal and cereal product samples weighing not less than $1 \mathrm{~kg}$ were taken according with Commission Regulation (EC) No. 406/2006 by employees of the State Sanitary Inspection [5]. As high differences between Fusarium toxin contamination levels were expected, some 100 samples were taken annually over the period from 2009 to 2012.357 samples were taken in total, in that:

- approx. 70\% wheat flour types 500 and 550,

- approx. $15 \%$ wheat flour type 2000 (full grain),

- approx. $15 \%$ rye flour.

Where possible, the samples originated from mills situated in area covered by the given Provincial Sanitary Epidemiological Station. The samples with their sampling protocols were submitted to the Food Safety Laboratory in National Institute of Public Health-National Institute of Hygiene (NIZP-PZH), where investigated mycotoxin levels were determined.

\section{Methodology of determination}

Tests were performed using own modification of the Sulyok high performance liquid chromatography coupled with mass spectrometry (HPLC-MS/MS) $[12,18]$. Pure for analysis Merck reagents were used, except for acetonitrile and ammonium acetate, with Baker purity for mass spectrometry quality. Standards, including radio-labeled standards were from Biopure. Reverse osmosis and dematerialized water was used. Method parameters have been stated in Tables 1 and 2. Precipitation data were taken from the Central Office of Statistics web page, and originated from the Institute of Meteorology and Water Management [22].

\section{RESULTS AND DISCUSSION}

Analysis of the influence of precipitation levels during vegetation period on mycotoxin levels in the investigated food stuffs was performed by associating each recorded content of deoxynivalenol $(n=52$, corresponding to $14.6 \%$ tested samples), zearalenone $(\mathrm{n}=30,8.4 \%)$, total T-2 and HT-2 toxins $(\mathrm{n}=21,5.9 \%)$ and ochratoxin $\mathrm{A}(\mathrm{n}=88,24.6 \%)$ above quantification limit with precipitation levels within the Province from which the sample originated. Precipitation levels from May to August were included, i.e. during period from cereal florescence to harvest. Fungi infections resulting in presence of Fusarium mycotoxins took place at that time. Presence of ochratoxin A, for which the highest number of contaminated samples was observed, results in turn from growth of Aspergillus ochraceus fungi after harvest, during storage of cereals. 
Weather conditions during harvest may be relevant for Figures 1. a) - d) present levels of mycotoxins reported growth of pathogenic fungi, but storage conditions of depending on precipitation levels. Extremely high cereals constitute a separate factor of key importance. mycotoxins level results of were discarded.

Table 1. Working conditions of MS / MS mass spectrometer (Waters Quattro Micro API MRM mode, ES + ionization

\begin{tabular}{|c|c|c|c|c|}
\hline Toxin /IS & Parent ion $(\mathrm{m} / \mathrm{z})$ & Daughter ion $(\mathrm{m} / \mathrm{z})$ & Cone voltage & Collision energy \\
\hline DON & 297.10 & 249.10 & 22 & 12 \\
\hline NIV & 313.10 & 125.00 & 24 & 12 \\
\hline ZEA & 319.20 & 301.00 & 21 & 10 \\
\hline OTA & 404.00 & 239.00 & 26 & 24 \\
\hline HT-2 & 442.2 & 263.20 & 18 & 13 \\
\hline HT-2 C13 (IS) & 464.3 & 278.1 & 20 & 14 \\
\hline $\mathrm{T}-2$ & 484.3 & 305.1 & 24 & 14 \\
\hline FB1 & 722.30 & 334.3 & 46 & 40 \\
\hline FB2 & 706.4 & 336.2 & 48 & 40 \\
\hline \multicolumn{5}{|c|}{ Source parameters } \\
\hline \multicolumn{2}{|r|}{ Capillary } & & \multicolumn{2}{|c|}{$4.00 \mathrm{kV}$} \\
\hline \multicolumn{2}{|r|}{ Cone } & & \multicolumn{2}{|c|}{$20.00 \mathrm{~V}$} \\
\hline \multicolumn{2}{|r|}{ Extractor } & & \multicolumn{2}{|c|}{$2.00 \mathrm{~V}$} \\
\hline \multicolumn{2}{|c|}{ Temperature } & & \multicolumn{2}{|c|}{$100^{\circ} \mathrm{C}$} \\
\hline \multirow{2}{*}{\multicolumn{2}{|c|}{$\begin{array}{l}\text { Evaporation temperature } \\
\text { Gas flow on the cone (N2) }\end{array}$}} & & \multicolumn{2}{|c|}{$350^{\circ} \mathrm{C}$} \\
\hline & & & \multirow{2}{*}{\multicolumn{2}{|c|}{$\frac{501 / h}{5001 / h}$}} \\
\hline \multicolumn{2}{|c|}{ Evaporative gas flow (N2) } & & & \\
\hline
\end{tabular}

Figure 1. Levels of occurrence of a) deoxynivalenol, b) zearalenone, c) the amount of T-2 and HT-2, and d) ochratoxin A in the test samples based on the total rainfall between May and August

a) deoxynivalenol

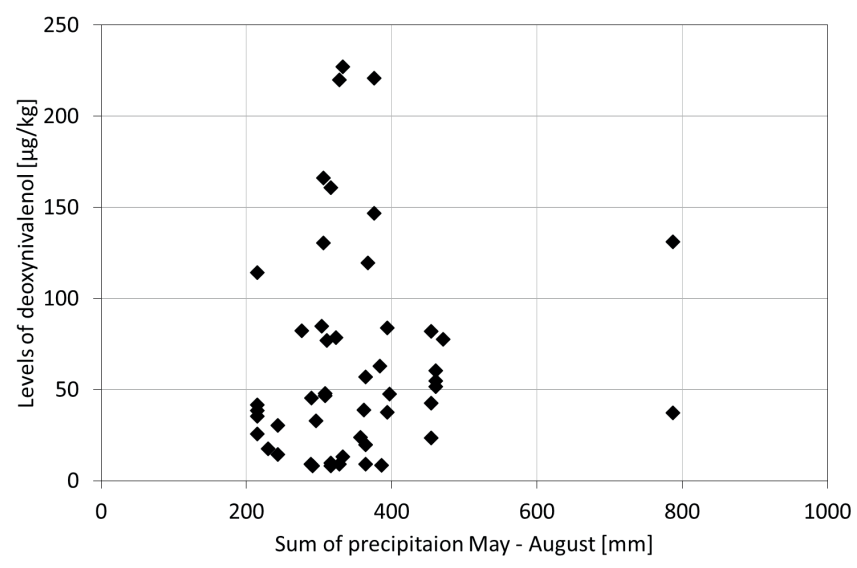

b) zearalenone

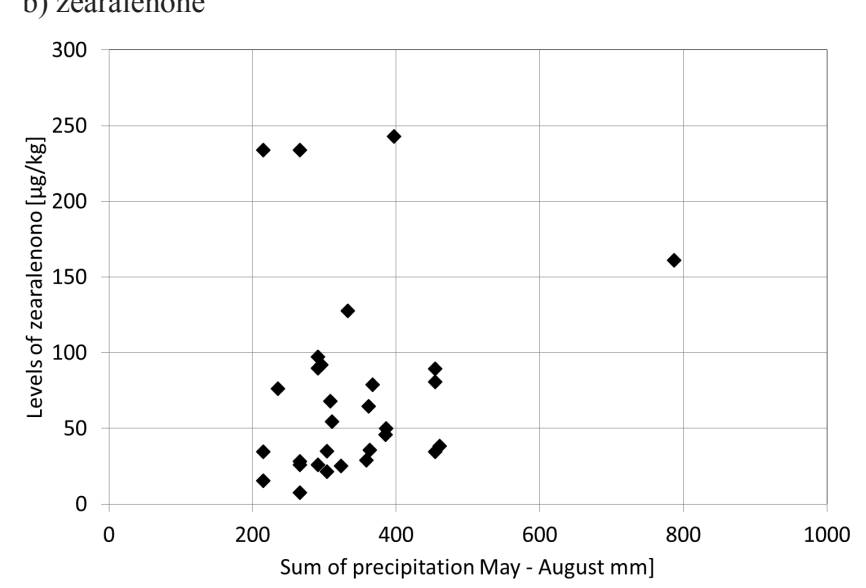

d) ochratoxin $\mathrm{A}$

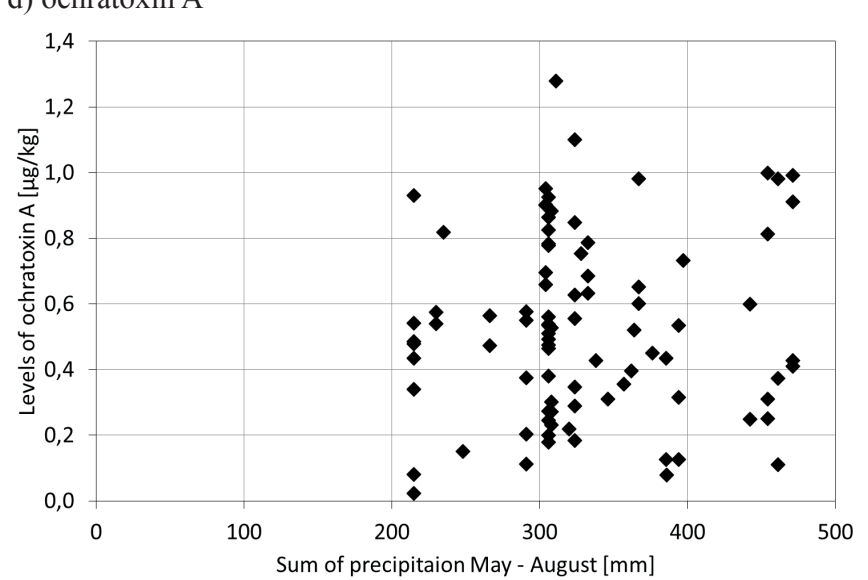

c) sum of T-2 i HT-2 toxin

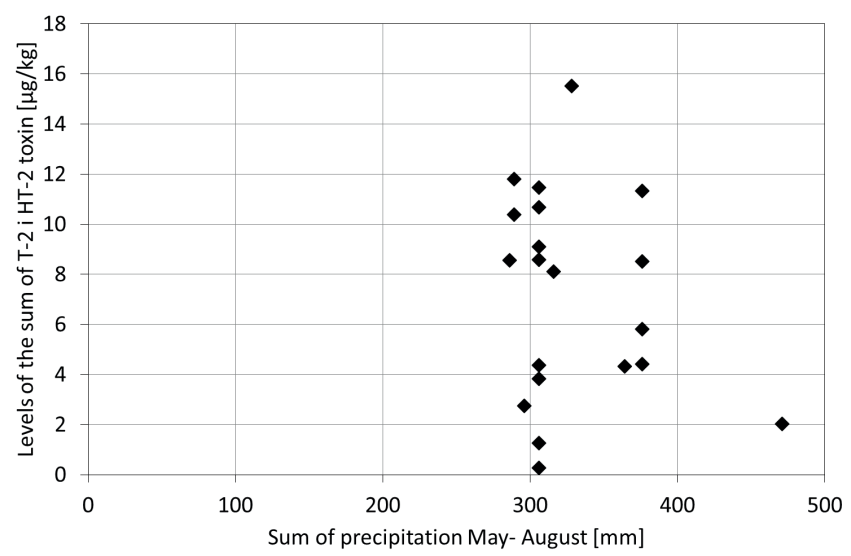


Observation of individual points does prove existence of link between precipitation levels and presence of mycotoxins. Absence of dependence for ochratoxin A could be justified by higher importance of storage conditions and short-term and local weather conditions during the harvest. T-2 and HT-2 toxins and zearalenone had relatively fewer results above the quantification limited (below 10\%), and these could have been insufficient to conclude existence of any dependence. Absence of any dependence between reported deoxynivalenol (frequent contaminant of cereals in Poland) levels and precipitation data is a more important finding. Probably, growth of toxin exuding fungi is considerably affected also by other factors and agricultural procedures, such as temperature during vegetation, pests, as well as crop-dusting. Lower temperatures coupled with high precipitation levels are disadvantageous for growth of Fusarium genus fungi.

A different approach may be taken by relating number of samples contaminated above/below the quantification limit with precipitation, and defining an average precipitation level for such subpopulation of samples for each of the investigated mycotoxins. Calculation results have been presented in Table 3.

Table 2. Performance of the analytical method

\begin{tabular}{|l|c|c|c|c|c|}
\hline \multicolumn{1}{|c|}{ Parameters } & DON & ZEA & OTA & HT-2 & T-2 \\
\hline Fortification level $(\mu \mathrm{g} / \mathrm{kg})$ & 100 & 10 & 0.25 & 7.5 & 7.5 \\
\hline Recovery $(\%)$ & 81.2 & 49.1 & 84.5 & 96.1 & 97.7 \\
\hline SD & 17.7 & 0.71 & 0.1099 & 1.20 & 0.47 \\
\hline RSD $(\%)$ & 5.1 & 14.4 & 65.1 & 14.3 & 6.5 \\
\hline Fortification level $(\mu \mathrm{g} / \mathrm{kg})$ & 200 & 20 & 0.5 & 15 & 15 \\
\hline Recovery $(\%)$ & 89.2 & 72.2 & 83.0 & 99.2 & 96.6 \\
\hline SD & 28.5 & 1.80 & 0.0897 & 1.08 & 1.18 \\
\hline RSD $(\%)$ & 6.4 & 12.5 & 14.5 & 6.8 & 8.2 \\
\hline Fortification level $(\mu \mathrm{g} / \mathrm{kg})$ & 400 & 40 & 1 & 30 & 30 \\
\hline Recovery $(\%)$ & 89.2 & 48.0 & 46.3 & 103.7 & 98.0 \\
\hline SD & 32.3 & 1.49 & 0.0849 & 1.31 & 1.77 \\
\hline RSD $(\%)$ & 5.2 & 7.8 & 12.7 & 4.0 & 6.0 \\
\hline
\end{tabular}

Table 3. Method performance parameters, detection limits (LOD) and quantification limits (LOQ)

\begin{tabular}{|c|c|c|c|c|}
\hline \multirow{2}{*}{ Mycotoxin } & \multicolumn{2}{|c|}{ LOD $(3 \times \mathrm{S} / \mathrm{N})$} & \multicolumn{2}{c|}{ LOQ $(10 \times \mathrm{S} / \mathrm{N})$} \\
\cline { 2 - 5 } & $\mathrm{ng} / \mathrm{ml}$ & $\mathrm{ng} / \mathrm{g}$ & $\mathrm{ng} / \mathrm{ml} / \mathrm{g}$ & 6.5 \\
\hline DON & 5.0 & 2.0 & 16.3 & 20.5 \\
\hline ZEA & 15.3 & 6.1 & 51.3 & 0.24 \\
\hline OTA & 0.18 & 0.07 & 9.3 & 3.7 \\
\hline HT-2 & 2.8 & 1.1 & 0.8 & 0.3 \\
\hline T-2 & 0.3 & 0.1 & & \\
\hline
\end{tabular}

However, also this approach does not lead to elucidating existence of a relationship between the number of contaminated samples and average precipitation levels. Precipitation levels for both populations are not significantly different: in case of deoxynivalenol, average precipitation level of contaminated samples is just slightly higher than for not contaminated ones (difference is $17.6 \mathrm{~mm}$, with standard deviation for precipitation level being 97.6 $\mathrm{mm}$ ). Precipitation level averages for zearalenone are identical in both analyzed subpopulations, and in case of total T-2 and HT-2 toxins, contaminated samples are associated with slightly lower precipitation levels as compared with the non-contaminated ones. A similar observation has been found for ochratoxin A, although it still lacks statistical significance; however, in this case the conclusion could be associated with higher importance of storage conditions as compared with cereal vegetation period.

Data for the collected 357 samples taken from all Provinces also allow analysis of external mycotoxin contents relative to external weather conditions. This model of research involved selecting two provinces where cereals are harvested: with lowest average total precipitation in May-August for a period of 4 years - Lubuskie and Łódzkie ( $\mathrm{n}=23$, average precipitation 31.4) and with highest total - Śląskie and Opolskie $(n=18$ average precipitation $498.8 \mathrm{~mm})$. Figure 2 for these Provinces presents average mycotoxin levels above quantification limit, ratio of the number of samples below and above quantification limit and precipitation level; comparative data for the entire 
country have been included, also. Such analysis was made for deoxynivalenol, zearalenone and ochratoxin A; total T-2 and HT-2 toxins in both compared areas had low incidence of results (just one value above $\mathrm{LOQ}=0.1 \mathrm{ng} / \mathrm{g}$ ). Graphs for deoxynivalenol and zearalenone show increase in average in line with increase in precipitation levels, thus proving to some extent the effect of increased precipitation levels on increase in mycotoxin content. Such trend is also visible for deoxynivalenol as an increase in the ratio of number of samples above the quantification limit to all samples taken in those areas. However, no clear trend is visible for zearalenone. In turn, the average contamination levels and ratios of numbers of samples in both compared areas do not differ significantly for ochratoxin A, confirming that weather conditions (precipitation) do not affect ochratoxin A levels.

Figure 2 The mean, minimum and maximum occurrence a) deoxynivalenol, b) zearalenone and c) ochratoxin A in the samples above the limit of quantification against the average rainfall in the provinces of extremely high and low average precipitation in 2009-2012. Percentage of samples above the limit of quantification against the amount of precipitation discussed.

a) deoxynivalenol
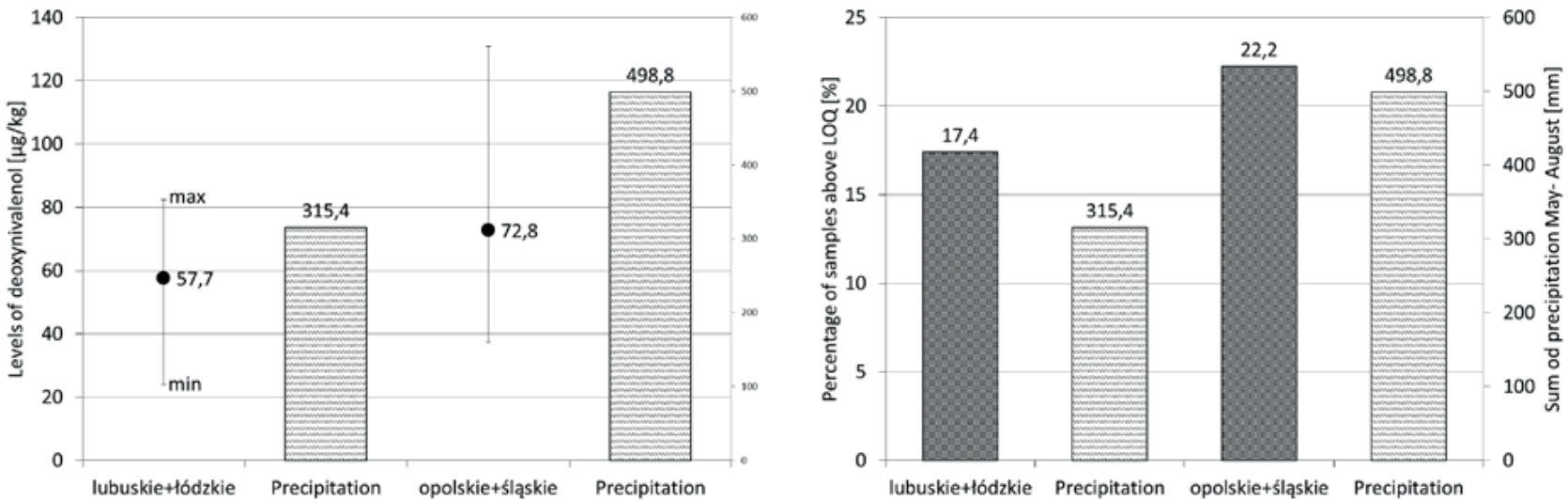

b) zearalenone
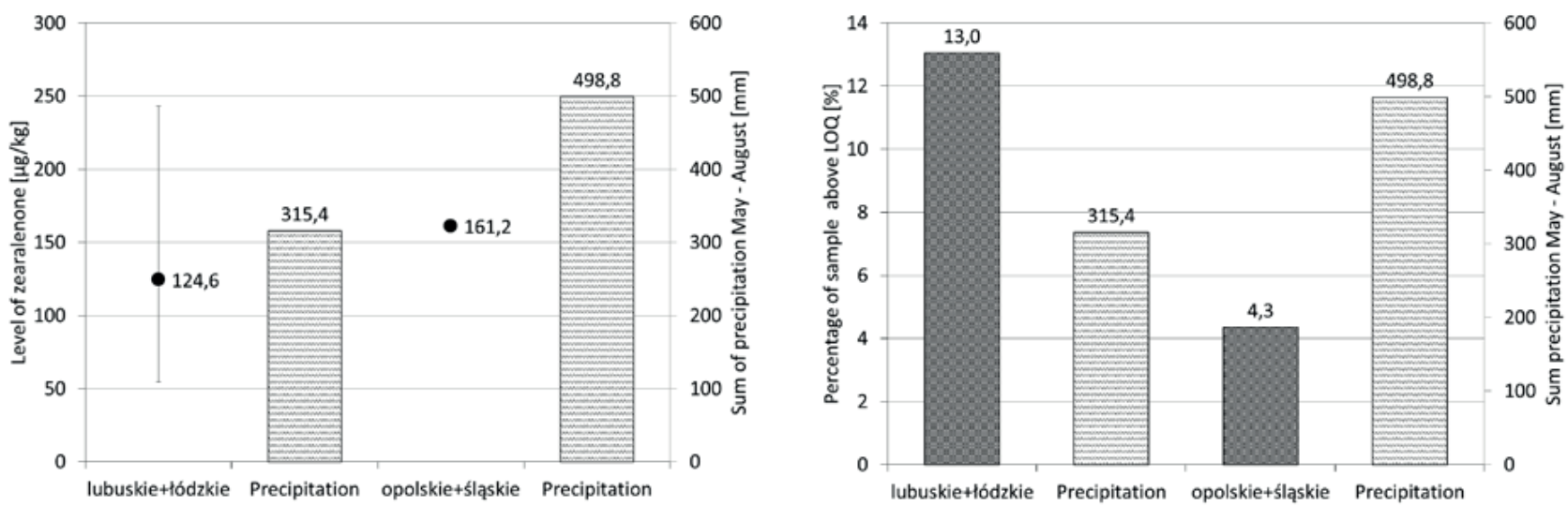

c) ochratoxin A
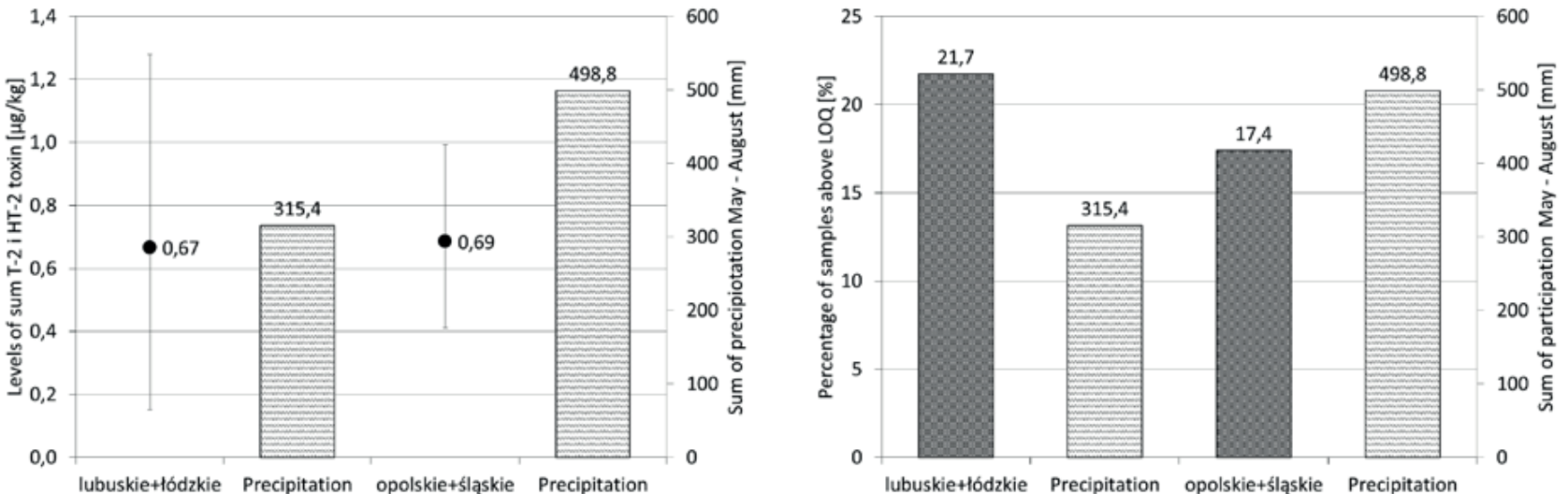
Data on presence of the investigated mycotoxins were collected in years 2009-2012, differing considerably in precipitation levels. Years 2009 and 2010 reported plentiful precipitation in the May to August period, whereas years 2011 and 2012 were more arid. Precipitation levels and mycotoxin presence results above the quantification limit for the entire Poland were compared over successive years and presented in Figure 3 and Table 4.

Figure 3. Mean values of occurrence a) deoxynivalenol, b) zearalenone and c) ochratoxin A in the samples above the limit of quantification in subsequent years to the sum of the four-year average precipitation in 2009-2012. Percentage of samples above the limit of quantification against the amount of precipitation discussed.

a) deoxynivalenol
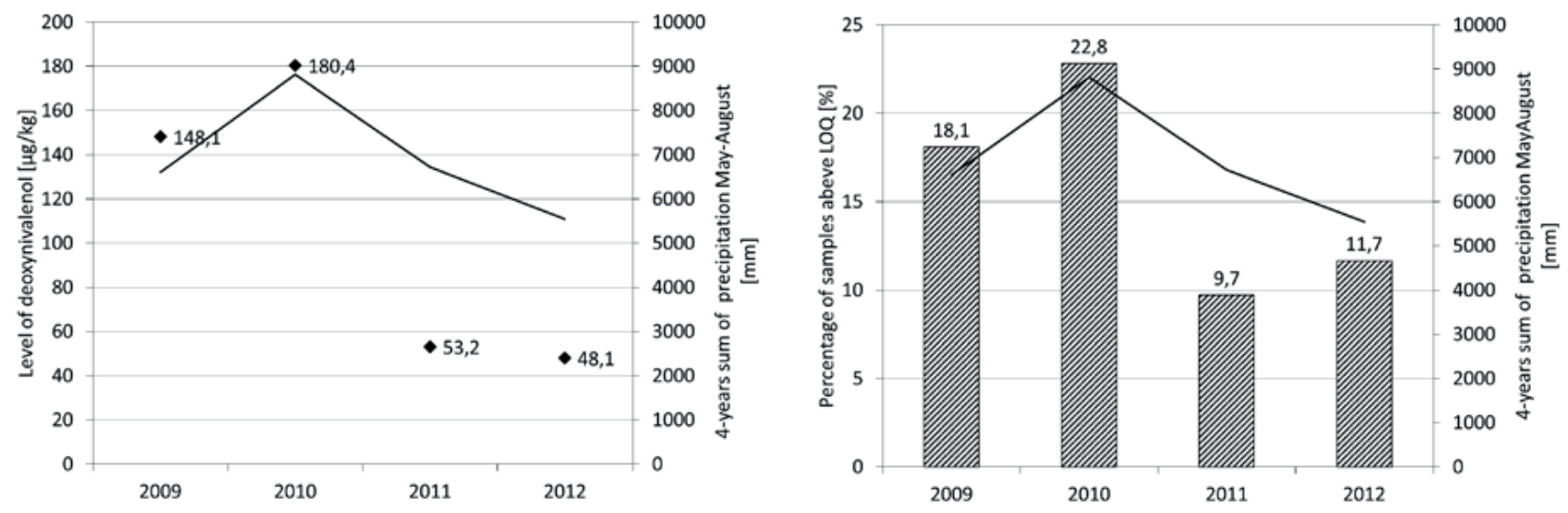

b) zearalenone
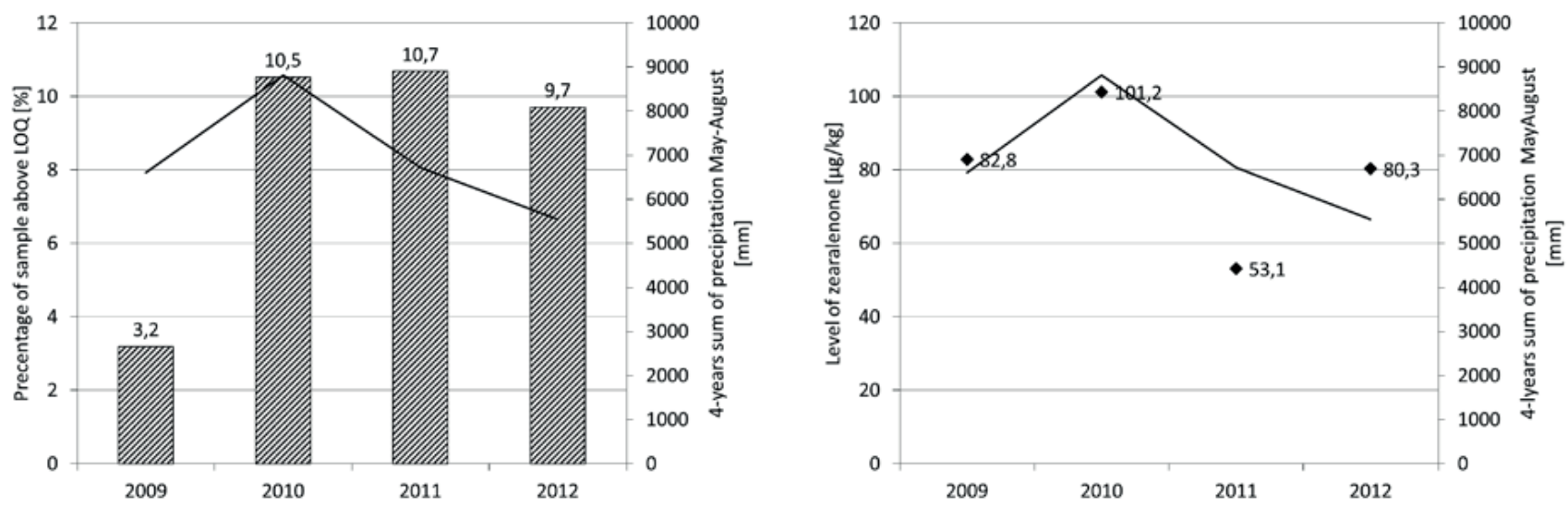

c) ochratoxin A
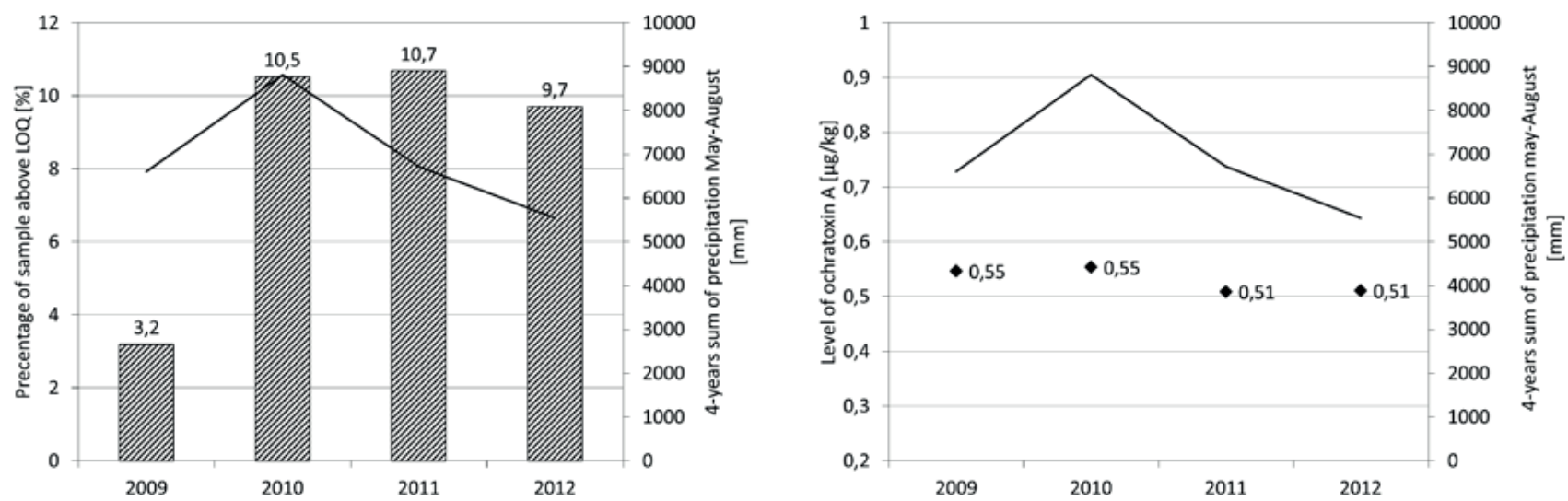
Table 4. Number of samples above and below the LOQ for each of the mycotoxins tested and average levels of total precipitation in May-August for both subpopulations of samples

\begin{tabular}{|c|c|c|c|c|c|c|c|c|}
\hline \multirow[b]{2}{*}{ Samples } & \multicolumn{2}{|c|}{ Deoxynivalenol } & \multicolumn{2}{|c|}{ Zearalenone } & \multicolumn{2}{|c|}{$\Sigma$ Toxins T-2 and HT- 2} & \multicolumn{2}{|c|}{ Ochratoxin A } \\
\hline & $\begin{array}{c}\text { Qty } \\
\text { (relative } \\
\text { qty) of } \\
\text { samples }\end{array}$ & $\begin{array}{c}\text { Average } \\
\text { precipitation } \\
(\mathrm{mm})\end{array}$ & $\begin{array}{c}\text { Qty } \\
\text { (relative } \\
\text { qty) of } \\
\text { samples }\end{array}$ & $\begin{array}{c}\text { Average } \\
\text { precipitation } \\
(\mathrm{mm})\end{array}$ & $\begin{array}{c}\text { Qty } \\
\text { (relative } \\
\text { qty) of } \\
\text { samples }\end{array}$ & $\begin{array}{c}\text { Average } \\
\text { precipitation } \\
(\mathrm{mm})\end{array}$ & $\begin{array}{c}\text { Qty } \\
\text { (relative } \\
\text { qty) of } \\
\text { samples }\end{array}$ & $\begin{array}{c}\text { Average } \\
\text { precipitation } \\
(\mathrm{mm})\end{array}$ \\
\hline$>$ LOQ & $\begin{array}{c}52 \\
(14.6 \%)\end{array}$ & 355.3 & $\begin{array}{c}30 \\
(8.4 \%)\end{array}$ & 340.9 & $\begin{array}{c}21 \\
(5.9 \%)\end{array}$ & 331.8 & $\begin{array}{c}88 \\
(24.6 \%)\end{array}$ & 330.5 \\
\hline$<$ LOQ & $\begin{array}{c}305 \\
(85.4 \%)\end{array}$ & 337.7 & $\begin{array}{c}327 \\
(91.6 \%)\end{array}$ & 340.2 & $\begin{array}{c}336 \\
(94.1 \%)\end{array}$ & 340.8 & $\begin{array}{c}269 \\
(75.4)\end{array}$ & 343.5 \\
\hline
\end{tabular}

A distinct variability of deoxynivalenol and zearalenone contamination is visible, corresponding with the changing precipitation levels and well reflecting the increased deoxynivalenol and zearalenone contents in the rainy years 2009-2010 relative to the more arid years 2011-2012. Variability of average ochratoxin A levels is not statistically significant. The relatively higher content of mycotoxins observed in 2009 may be a consequence of the heavy rain and floods of 2007-2008. Dependence has been observed for deoxynivalenol also between the precipitation levels and number of samples above the quantification limit. No significant dependence has been found in similar analysis for zearalenone and ochratoxin A. Data analysis for total of T-2 and HT-2 toxins was not possible due to insufficient number of samples. However, it should be noted that $21 \%$ investigated samples contained total $\mathrm{T}-2$ and HT-2 toxin levels above the quantification limit, with average contamination levels at $8.9 \mu \mathrm{g} / \mathrm{kg}$, whereas in 2010-2012 just one sample in 263 was reported to be contaminated with those toxins at level exceeding the quantification limit.

Use of mathematical models for quantification and forecasting microbiological behaviors. Predictive microbiology for forecasting presence of pathogens transferred through foodstuffs has been under development for some 20 years, notwithstanding primary application of such tools to bacteria. Prognostic mycology focused on food safety is much less advanced $[1,7,17]$.

Mycotoxins present in agricultural commodities constitute a safety threat to foodstuffs during transport, storage and distribution [20]. The specific variability of factors responsible for generation of mycotoxins continues to pose a challenge, with the existing research referring either to laboratory or global scale models of forecasting changes. In summary, forecasting levels of mycotoxins present in foodstuffs and animal fodder is difficult due to the divergence of factors affecting their generation.

Table 5. Mean values of occurrence of mycotoxins in samples above the limit of quantification (LOQ) and the percentage of samples above the LOQ in each year to the sum of the 4-year average rainfall in 2009-2012

\begin{tabular}{|c|c|c|c|c|c|c|c|c|}
\hline \multirow[b]{2}{*}{ Year } & \multirow[b]{2}{*}{$\begin{array}{c}\text { Number of } \\
\text { samples }\end{array}$} & \multicolumn{2}{|c|}{ Deoxynivalenol } & \multicolumn{2}{|c|}{ Zearalenone } & \multicolumn{2}{|c|}{ Ochratoxin A (OTA) } & \multirow[b]{2}{*}{$\begin{array}{l}\text { 4-year total } \\
\text { rainfall } \\
(\mathrm{mm})\end{array}$} \\
\hline & & $\begin{array}{c}\text { Number of } \\
\text { samples } \\
>\text { LOQ }\end{array}$ & $\begin{array}{c}\text { Mean } \\
(\mu \mathrm{g} / \mathrm{kg})\end{array}$ & $\begin{array}{l}\text { Number of } \\
\text { samples } \\
\text { > LOQ }\end{array}$ & $\begin{array}{c}\text { Mean } \\
(\mu \mathrm{g} / \mathrm{kg})\end{array}$ & $\begin{array}{l}\text { Number } \\
\text { of samples } \\
\text { > LOQ }\end{array}$ & $\begin{array}{c}\text { Mean } \\
(\mu \mathrm{g} / \mathrm{kg})\end{array}$ & \\
\hline 2009 & 94 & $\begin{array}{c}17 \\
(18.1 \%)\end{array}$ & 148.1 & $\begin{array}{c}3 / 94 \\
(3.2 \%)\end{array}$ & 82.83 & $\begin{array}{c}31 \\
(33.0 \%)\end{array}$ & 0.55 & 6602 \\
\hline 2010 & 57 & $\begin{array}{c}13 \\
(22.8 \%) \\
\end{array}$ & 180.4 & $\begin{array}{c}6 \\
(10.5 \%) \\
\end{array}$ & 101.2 & $\begin{array}{c}8 \\
(14.0 \%) \\
\end{array}$ & 0.55 & 8812 \\
\hline 2011 & 103 & $\begin{array}{c}10 \\
(9.7 \%) \\
\end{array}$ & 53.2 & $\begin{array}{c}11 \\
(10.7 \%)\end{array}$ & 53.1 & $\begin{array}{c}28 \\
(27.2 \%)\end{array}$ & 0.51 & 6717 \\
\hline 2012 & 103 & $\begin{array}{c}12 \\
(11.6 \%)\end{array}$ & 48.1 & $\begin{array}{c}10 \\
(9.7 \%)\end{array}$ & 80.3 & $\begin{array}{c}21 \\
(20.4 \%)\end{array}$ & 0.51 & 5541 \\
\hline 2009-2012 & 357 & $\begin{array}{c}52 \\
(14.6 \%)\end{array}$ & 114.8 & $\begin{array}{c}30 \\
(8.4 \%)\end{array}$ & 79.4 & $\begin{array}{c}88 \\
(24.6 \%)\end{array}$ & 0.53 & \\
\hline
\end{tabular}

\section{CONCLUSIONS}

1. The model for forecasting presence of mycotoxins in cereals does not allow its practical use during the routine of establishing official control and monitoring plans on the national scale.
2. Although adverse weather conditions prevailed during these investigations, exceeding of highest permitted contamination levels happened just incidentally.

3. Further systematic collection of data on mycotoxin contamination of agricultural crops is required for effective continued investigations. 


\section{Acknowledgments}

This study was financially supported by the National Science Centre in Poland within the research project NN404 124540.

\section{Conflict of interest}

The authors declare no conflict of interest.

\section{REFERENCES}

1. Aldars-Garcia, L., Ramos, A. J., Sanchis, V., Marin, $S$.: Modeling postharvest mycotoxins in foods: recent research. Current Opinion in Food Science, 2016, 11, 46-50. https://doi.org/10.1016/J.COFS.2016.09.005

2. Appropriateness to set a group health-based guidance value for zearalenone and its modified forms. (2016). EFSA Journal, 14(4), e04425. https://doi.org/ doi:10.2903/j.efsa.2016.4425.

3. Arcella, D., Gergelova, P., Innocenti, M. L., Steinkellner, $H$.: Human and animal dietary exposure to $\mathrm{T}-2$ and HT-2 toxin. EFSA Journal 2017;15(8), e04972. https:// doi.org/doi:10.2903/j.efsa.2017.4972

4. Commission Regulation (EC) No 1881/2006 of 19 December 2006 setting maximum levels for certain contaminants in foodstuffs (as amended) OJ L 364, 20.12.2006, p. 5-24

5. Commission Regulation (EC) No 401/2006 of 23 February 2006 laying down the methods of sampling and analysis for the official control of the levels of mycotoxins in foodstuffs (as amended) OJ L 70, 9.3.2006, p. 12-34.

6. European Commission. Collection of occurrence data of Fusarium toxins in food and assessment of dietary intake by the population of EU Member States, SCOOP task 3.2.10 2003.

7. Garcia, D., Ramos, A. J., Sanchis, V., Marín, S.: Predicting mycotoxins in foods: A review. Food Microbiology, 2009;26(8):757-769. https://doi.org/10.1016/J. FM.2009.05.014

8. GEMS/Food regional diets: regional per capita consumption of raw and semi-processed agricultural commodities, prepared by the Global Environment Monitoring System/Food Contamination Monitoring and Assessment Programme. WHO, 2006. http://www.who. int/foodsafety/chem/gems_regional_diet.pdf.

9. IARC. Monographs on the evaluation of carcinogenic risks to humans; Vol. 56: Some naturally occurring substances, food items and constituents, heterocyclic aromatic amines and mycotoxins. International Agency for Research on Cancer, World Health Organization, 1993, 397-433

10. Knutsen H. K., Barregård L., Bignami M., Brüschweiler B., Ceccatelli S., Cottrill B., Alexander J.: Appropriateness to set a group health based guidance value for nivalenol and its modified forms. EFSA Journal 2017;15(4): e04751. https://doi.org/doi:10.2903/j.efsa.2017.4751
11. Knutsen, H.-K., Barregård, L., Bignami, M., Brüschweiler, B., Ceccatelli, S., Cottrill, B., Alexander, J.: Appropriateness to set a group health based guidance value for T2 and HT2 toxin and its modified forms. EFSA Journal 2017; 15(1): e04655. https://doi.org/ doi:10.2903/j.efsa.2017.4655

12. Krska R., Molinelli I.: Mycotoxin analysis: stateof-the-art and future trends. Bioanal Chem. Anal. 2007;387:145-8.

13. Magan N., Aldred D.: Post-harvest control strategies: Minimizing mycotoxins in the food chain. Int. J of Food Microbiology. 2007;119:131-139.

14. Miraglia M., Marvin HJ., Kleter GA., Battilani P., Brera C., Coni E., Cubadda F., Croci L., De Santis B., Dekkers S., Filippi L., Hutjes R.W., Noordam M.Y., Pisante M., Piva G., Prandini A., Toti L., van den Born G.J., Vespermann A.: Climate change and food safety: An emerging issue with special focus on Europe. Food Chem Toxicol 2009;47:1009-1021.

15. Morgavi D.P., Riley R.T.: An historical overview of field disease outbreaks known or suspected to be caused by consumption of feeds contaminated with Fusarium toxins. Anim. Feed Sci. Technol. 2007;137:201-212.

16. Mossa M., Thrane U.: Fusarium taxonomy with relation to trichothecene formation. Toxicology Letters 2004;153;23-28

17. Pasquali F., Brochot C., Cocco E. Hoffmann L., Bohn $T$.: Genetic Fusarium chemotyping as a useful tool for predicting nivalenol contamination in winter wheat. Int. J. Food Microbiol 2010;137:246-253.

18. Postupolski J., Starski A., Ledzion E., KurpińskaJaworska J., Szczęsna M.: Exposure assessment of infants and young children on selected fusarium toxin toxins Rocz Panstw Zakl Hig 2019;70(1):5-14. DOI: https://doi.org/10.32394/rpzh.2019.0050

19. Postupolski J., Rybińska K., Ledzion E., KurpińskaJaworska J., Szczesna M., Karlowski K.: Monitoring programme of T-2 and HT-2 toxins level in cereal products Rocz Panstw Zakl Hig 2008;59(1):429-35.

20. Schrödter R: Influence of harvest and storage conditions on trichothecenes levels in various cereals. Toxicol Letters 2004;153:47-49.

21. Scientific Opinion on the risks for human and animal health related to the presence of modified forms of certain mycotoxins in food and feed. EFSA Journal 2014;12(12):3916. https://doi.org/doi:10.2903/j. efsa.2014.3916

22. Vogelgsang S., Musa T., Bänziger I.: Fusarium Mycotoxins in Swiss Wheat: A survey of growers' samples between 2007 and 2014 shows strong year and minor geographic effects. Battilani P. (ed. ), Toxins (Basel), 2017;9(8):246. doi:10.3390/toxins9080246

Received: 17.09.2018

Accepted: 20.03.2019

This article is available in Open Access model and licensed under a Creative Commons Attribution-Non Commercial 3.0.Poland License (CC-BY-NC) available at: http://creativecommons.org/licenses/by-nc/3.0/pl/deed.en 